\title{
腔癌に対するエスキノンの臨床効果
}

\author{
金田 敏 郎・小谷順一郎・田口望 \\ 市川均・服部吉之助
}

\section{Clinical result on Esquinone in treatment of oral cancer}

\author{
Toshio Kaneda - Junichiro Kotani - Nozomu TAguchI \\ Hitoshi ICHIKAwA $\cdot$ Kichinosuke HATtORI
}

\begin{abstract}
緒
言

エスキノン（以下 $\mathrm{CQ}$ と略）は合成されたアルキル 化剂系抗癌剂で, その構造はマイトマイシンCに類似し， DNA 合成阻害作用により抗癌作用を示すとされてい る1,2)．臨床上では特に白血病に対してすぐれた成績が 示されているが3 9), 各種蔵器の固型腫瘍に 対しての制 癌効果も報告されている(10 30). 一方, 頭頸部癌に対する 治療成績は少なく，上顎癌の 4 例に使用した武井ら ${ }^{30}$ )の 報告のみである。われわれは各種口腔癌 9 例に本剤を主 体とした療法を行い，その抗癌効果について臨床的検討 を行った。
\end{abstract}

\section{対象症例と投与方法}

対象症例は上買癌 2 例, 下顎癌 2 例, 煩粘膜癌 2 例, 舌癌 3 例（男 6 例, 女 3 例, $47 \sim 76$ 歳) で, 病理組織学 的診断は症例 1 の下顎癌が adenoid cystic carcinoma であった以外はすべて squamous cell carcinoma であ った.

$\mathrm{TNM}$ 分類は $\mathrm{T}_{2} 4$ 例, $\mathrm{T}_{3} 3$ 例, $\mathrm{T}_{4} 2$ 例, $\mathrm{N}$ は $\mathrm{N}_{0}$ 3 例, $\mathrm{N}_{1} 3$ 例, $\mathrm{N}_{2} 1$ 例, $\mathrm{N}_{3} 2$ 例で, $\mathrm{M}$ はすべて $\mathrm{M}_{0}$ であった。なお臨床病態は 9 例中 1 次症例は 5 例（症例 1〜 5)，2 次症例は 4 例（症例 $6 〜 9$ ）であった.

$\mathrm{CQ}$ 投与方法は 1 次症例に対しては外来で確定診断 後, ただち CQ の点滴静注（1〜 $5 \mathrm{mg}$ /回）を週 2 回 の頻度で開始した，CQ 治療開始後, 患者は可及的速か に入院させ，浅側頭動脈より持続動注（1 mg/日）に変 更するよらにした。 なお， 1 次症例では CQ 単独の制 癌効果を検討するため, 原則として他制癌剂, 他制癌治 療の併用をさけるようにしたが，5例中の 2 例に他療法

名古屋大学医学部口腔外科学苝座（主任：岡逹 教授)

Department of Oral Surgery, Nagoya University, School of Medicine (Chief: Prof. Toru Oka) 受付日：昭和 52 年 12 月 19 日
を併用した。すなわち 1 例（症例 1) は picibanil (59.4 KE) を，ほかの 1 例（症例 5) では BLM (140 mg)

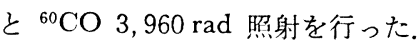

CQ 内服を行ったものは 7 例で，その内訳は種々の 1 次治療に抵抗を示した 2 次症例（症例 $6 〜 9$ ） 4 例と 1 次症例で 1 次治療に CQ の静, 動注を行ったのち手 術療法を採用した 3 例（症例 1，2，4）に adjuvant chemotherapy として投与した。いずれも外来通院中に 投与したもので，1 日投与量は $0.5 \sim 0.75 \mathrm{mg}$ で，投与 期間は 33〜153 日間連続内服せしぬた。

\section{臨 床 成 績}

1 次症例で動注を行った 5 例では 4 例に臨床的に軽度 腫瘦の縮小傾向を認めた。有効と判定された症例はいず れも扁平上皮癌で，無効とされたものは腺様整胞癌であ った。しかし CQ 療法終了後行った病理組織学的検討 で，腫㿇細胞に変性傾向を認めたものは 2 例（症例 4 , 5 )で, ほかの 3 例は病理組織学的に顕著な変化はみら れなかった。病理組織学的に変性傾向を認めたものの 1 例（症例 4 , 後詳記）は，CQ 投与前後で BLM（105 mg) の投与が行われており，またほかの 1 例（症例 5 ） では $\mathrm{BLM}$ と ${ }^{60} \mathrm{CO}$ 照射が併用され，しかも全身性丘 疹性発疹のため CQ 療法が途中で中止されていること など勘案すると，その効果判定には慎重であらねばなら ない

臨床的に有効と判定された症例も CQ 投与によって 腫瘍の完全寛解を期待するには困難と推測されたので, 最終的に全例に手術療法を適応した。昭和 52 年 7 月現 在，最短 1 年 11 か月，最長 2 年 3 か月の経過期である が, 全例生存中で局所再発, 転移徵候もなく社会復帰し ている.

内服治療を行ったものは 2 次症例 4 例を主体に adjuvant chemotherapy の 3 例と 7 例に投与を行った。この 5ち 2 次症例の 4 例について検討与ると， 3 例死亡（腫 瘍死），1例（症例 6 ）は治療中に所属リンパ節に転移 が起こった（廍清手術により生存中）. 
表 1 対象症例と CQ 盽法

\begin{tabular}{|c|c|c|c|c|c|c|c|c|c|}
\hline \multirow[b]{2}{*}{$\begin{array}{l}\text { 症例 } \\
\text { 番号 }\end{array}$} & \multirow[b]{2}{*}{ 氏 名 } & \multirow[b]{2}{*}{ 性 } & \multirow[b]{2}{*}{ 年龄 } & \multirow[b]{2}{*}{$\begin{array}{c}\text { 臨床診断 } \\
\text { TNM }\end{array}$} & \multirow[b]{2}{*}{$\begin{array}{l}\text { 病理組織 } \\
\text { 診 断 }\end{array}$} & \multicolumn{2}{|l|}{ 前 咍 療 } & & \\
\hline & & & & & & $\begin{array}{l}\text { 放射線療法 } \\
\text { 化学遼法 } \\
\text { 手 }\end{array}$ & 奻 果 & \multicolumn{2}{|c|}{ 投与経路 } \\
\hline \multirow{2}{*}{1} & & \multirow{2}{*}{ 男 } & \multirow{2}{*}{47} & \multirow{2}{*}{$\begin{array}{l}\text { 下 䫇 癌 } \\
\mathrm{T}_{4} \mathrm{~N}_{1} \mathrm{M}_{0}\end{array}$} & \multirow{2}{*}{$\begin{array}{l}\text { ad. } \\
\text { cyst. } \\
\text { ca. }\end{array}$} & & & 静 & 注 \\
\hline & & & & & & & & 動 & 注 \\
\hline \multirow{2}{*}{2} & & \multirow{2}{*}{ is } & \multirow{2}{*}{76} & \multirow{2}{*}{$\begin{array}{l}\text { 類粘膜癌 } \\
\mathrm{T}_{2} \mathrm{~N}_{3} \mathrm{M}_{0}\end{array}$} & \multirow{2}{*}{$\begin{array}{l}\text { Sq. cell } \\
\text { ca. }\end{array}$} & & & 静 & 注 \\
\hline & & & & & & & & 動 & 注 \\
\hline \multirow{2}{*}{3} & & \multirow{2}{*}{ "I } & \multirow{2}{*}{50} & \multirow{2}{*}{$\frac{\text { 上顎 }}{\mathbf{T}_{3} \mathbf{N}_{1} \mathbf{M}_{0}}$} & \multirow{2}{*}{ " } & & & 静 & 注 \\
\hline & & & & & & & & 動 & 注 \\
\hline \multirow{2}{*}{4} & & \multirow{2}{*}{ 女 } & \multirow{2}{*}{49} & \multirow{2}{*}{ 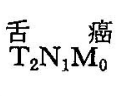 } & \multirow{2}{*}{$\|$} & & & 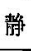 & 注 \\
\hline & & & & & & & & 動 & 注 \\
\hline \multirow{2}{*}{5} & & \multirow{2}{*}{ 男 } & \multirow{2}{*}{55} & \multirow{2}{*}{$\begin{array}{l}\text { 頼粘膜癌 } \\
\mathrm{T}_{2} \mathrm{~N}_{2} \mathrm{M}_{0}\end{array}$} & \multirow{2}{*}{ " } & & & 静 & 注 \\
\hline & & & & & & & & 動 & 注 \\
\hline 6 & & 女 & 60 & $\frac{\text { 上 }}{\mathrm{T}_{3} \mathrm{~N}_{0} \mathrm{w}_{0} \mathrm{M}_{0}}$ & "I & $\begin{array}{l}\text { Linac X } \\
\text { BAR, MMC, } 5 F U, O K \\
\text { 眼摘上顎切除 }\end{array}$ & (再 ${ }^{-}$然) & 経 & 口 \\
\hline 7 & & 男 & 75 & $\begin{array}{l}\text { 下 顎 癌 } \\
\mathrm{T}_{4} \mathrm{~N}_{0} \mathrm{M}_{0}\end{array}$ & "I & BAR & (残 存) & 絴 & 口 \\
\hline 8 & & $"$ & 71 & 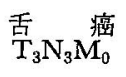 & " & $\begin{array}{l}\text { BAR } \\
{ }^{60} \mathrm{CO} \text { BLM }\end{array}$ & (笺 & 経 & 口 \\
\hline 9 & & 女 & 67 & 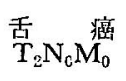 & "I & $\begin{array}{l}\text { BAR } \\
\text { 舌部切 }\end{array}$ & （䂝 存） & 経 & 口 \\
\hline
\end{tabular}

adjuvant chemotherapy の 3 例は, いずれも curative operation が施行されているので，本剤の効果によると 断定はできないが，先記したごとくいずれす生存してい、 万.

次に臨床的, 病理組織学的に効果が認められた症例の 臨床経過を詳記する.

症例 4: 49歲 主婦。

初 診: 昭和50年 4 月日日.

主 訴: 右舌縁接蚛痏.

診 断: 右舌癌, $\mathrm{T}_{2} \mathrm{~N}_{1} \mathrm{M}_{0}$, well differentiated squamous cell carcinoma.

既往歴：特記することなし。

家族歴：特記することなし。

現病歴: 昭和49年10月ごろ, 右舌縁中央部が発赤して いるのに気付いた．粆純な炎症と考え放固していたとこ ろ，2か月後ごろより次第に発赤笓困が增大し，同時に 接触痛を自覚するよらになった，某外科医院を受診し， 同院より紹介来院した。

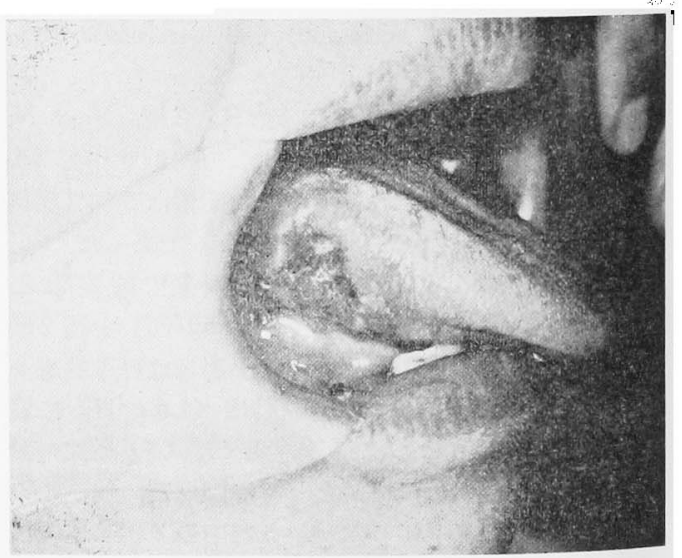

図 1 初診時 (50年 4 月曰日) 病態 渱瘍 : $25 \times 15 \mathrm{~mm}$, 硬結 : $30 \times 20 \mathrm{~mm}$

現 症

全身所見は買常なし，在舌縁で舌根に近い部位に25x 
よよび前後の治療内容

\begin{tabular}{|c|c|c|c|c|c|c|c|c|}
\hline \multicolumn{7}{|c|}{ CQ 療 法 } & \multirow[b]{2}{*}{ CQ 療法後治療内容 } & \multirow[b]{2}{*}{$\begin{array}{l}\text { 転 帰 } \\
\text { 生存日数 }\end{array}$} \\
\hline \multicolumn{2}{|c|}{ 投 与 量 } & $\begin{array}{l}\text { 同 時 } \\
\text { 垪用療法 }\end{array}$ & 副作用 & 臨床 & 病理 & $\begin{array}{l}\text { 効果 } \\
\text { 判定 }\end{array}$ & & \\
\hline $23 \mathrm{mg}$ & \multirow{2}{*}{$61 \mathrm{mg}$} & \multirow{2}{*}{ OK } & \multirow{2}{*}{$\begin{array}{l}\text { 脱 毛 } \\
\text { 白血球減少 }\end{array}$} & \multirow{2}{*}{-} & \multirow{2}{*}{-} & \multirow{2}{*}{-} & 顎骨半側切除，頸廟 & \multirow{2}{*}{ 生存 } \\
\hline $38 \mathrm{mg}$ & & & & & & & $\mathrm{CQ}$ (経口 $44.5 \mathrm{mg}$ ) & \\
\hline $27 \mathrm{mg}$ & \multirow{2}{*}{$41.4 \mathrm{mg}$} & & \multirow{2}{*}{$\begin{array}{l}\text { 白血球減少 } \\
\text { 血小板隇少 } \\
\text { 下菻 }\end{array}$} & \multirow{2}{*}{+} & \multirow{2}{*}{-} & \multirow{2}{*}{-} & BAR，FT，5FU（経口） & \multirow{2}{*}{ 生存 } \\
\hline $14.4 \mathrm{mg}$ & & & & & & & 尰場摘出, 皮膚移植 & \\
\hline $41 \mathrm{mg}$ & \multirow{2}{*}{$49.2 \mathrm{mg}$} & & \multirow{2}{*}{ 白血球隇少 } & \multirow{2}{*}{+} & \multirow{2}{*}{-} & \multirow{2}{*}{-} & BAR, FT, OK & \multirow{2}{*}{$\begin{array}{l}\text { 生 存 } \\
2 \text { 年 } 2 \text { 员 }\end{array}$} \\
\hline $8.2 \mathrm{mg}$ & & & & & & & 上顥切除，頸廓 & \\
\hline $12 \mathrm{mg}$ & \multirow{2}{*}{$30 \mathrm{mg}$} & & \multirow{2}{*}{$\begin{array}{l}\text { 脱毛, 蚠血 } \\
\text { 白血球減少 } \\
\text { 血小板減少 }\end{array}$} & \multirow{2}{*}{+} & \multirow{2}{*}{$\left(\begin{array}{c}+ \\
\text { 変性 } \\
\text { 軽度 }\end{array}\right)$} & \multirow{2}{*}{+} & BLM & \multirow{2}{*}{ 生 存 } \\
\hline $18 \mathrm{mg}$ & & & & & & & $\mathrm{BLM}, \mathrm{CQ}$ (経口 $44.25 \mathrm{mg}$ ) & \\
\hline $3 \mathrm{mg}$ & \multirow{2}{*}{$12 \mathrm{mg}$} & \multirow{2}{*}{$\begin{array}{l}\mathrm{BLM} \\
{ }^{60} \mathrm{CO}\end{array}$} & \multirow{2}{*}{$\begin{array}{l}\text { 乓疹性発疹 } \\
\text { 食 思不振 }\end{array}$} & \multirow{2}{*}{+} & \multirow{2}{*}{ 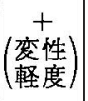 } & \multirow{2}{*}{+} & \multirow{2}{*}{$\begin{array}{l}\mathrm{BLM},{ }^{60} \mathrm{CO} \\
\text { 腫演摘出, 皮盧移植 }\end{array}$} & \multirow{2}{*}{$\begin{array}{l}\text { 生 存 } \\
1 \text { 年11か月 }\end{array}$} \\
\hline $9 \mathrm{mg}$ & & & & & & & & \\
\hline 20.3 & mg & $\begin{array}{l}\text { FT } \\
\text { OK } \\
\text { oil } \mathrm{BLM}\end{array}$ & $\begin{array}{l}\text { 白血球減少 } \\
\text { 血小板減少 }\end{array}$ & - & - & - & $\begin{array}{l}5 F U \text { (経口) } \\
\text { PSK } \\
\text { 頸 廓 }\end{array}$ & 生存 \\
\hline 65.2 & $\mathrm{mg}$ & $\begin{array}{c}5 F U \\
\text { (経口) }\end{array}$ & & - & - & - & 5FU（経口） & $\begin{array}{l}\text { 腫瘍死 } \\
4 \text { か月 }\end{array}$ \\
\hline 24.7 & $\mathrm{mg}$ & BLM & & - & - & - & $\begin{array}{l}\text { 舌切除, 頸廟 } \\
5 \mathrm{FU}, \mathrm{MLC}, \mathrm{BLM} \\
\text { 丸山ワクチン }\end{array}$ & $\begin{array}{l}\text { 腫瘤死 } \\
1 \text { 年 } 8 \text { か月 }\end{array}$ \\
\hline 76.5 & $\mathrm{mg}$ & FT & & - & - & - & $\begin{array}{l}\text { 舌切除, 顎骨半側切除, 顧廓 } \\
5 \mathrm{FU}, \mathrm{FT} \text {, OK }\end{array}$ & $\begin{array}{l}\text { 腫璸死 } \\
1 \text { 年11か月 }\end{array}$ \\
\hline
\end{tabular}

$15 \mathrm{~mm}$ のほぼ円形の浅い潰瘍があり，潰港中央には小 豆大の小隆起が認められた，潰瘍周囲は堤防状軽度に隆 起し，この周囲に $30 \times 20 \mathrm{~mm}$ の硬結が触知できた。初 診当日，墨性尰瘍寲診で病理組織検查を施行するととも K, BLM $7.5 \mathrm{mg}$ one shot に静注した. (病理組織 診断確定までに BLM $30 \mathrm{mg}$ を静注した).

\section{治療経過および CQ による効果}

病理組織診断確定後, 入院までの3 週間は外来通院で 週 I回 $\mathrm{CQ}$ の点滴静注 ( $1 \mathrm{mg}, 5 \mathrm{mg}, 6 \mathrm{mg}$, 計 $12 \mathrm{mg}$ ) を行った. $\mathrm{CQ}$ 点滴静注によって潰痬は，いくぶんか縮 小したよらな印象を持ったが，腫瘍実測値には変化は認 められなかった．白血球の減少はＩ mg 静注後のI週間 目より，その傾向を認めた。昭和50年 5 月曰日に入院さ せただらに浅側頭動脈より CQ $1 \mathrm{mg} /$ 日の持続動注 (Heparin 1,000 単位/日, Urokinase 6,000 単位/日) 開始した，5月日日でに $10 \mathrm{mg}$ を動注（初回より の総投与量 $22 \mathrm{mg}$ ）し，蛽瘍は $11 \times 11 \mathrm{~mm}$, 硬結 $13 \times$ $17 \mathrm{~mm}$ に縮小してきた。しかし CQ 静注開始直後より

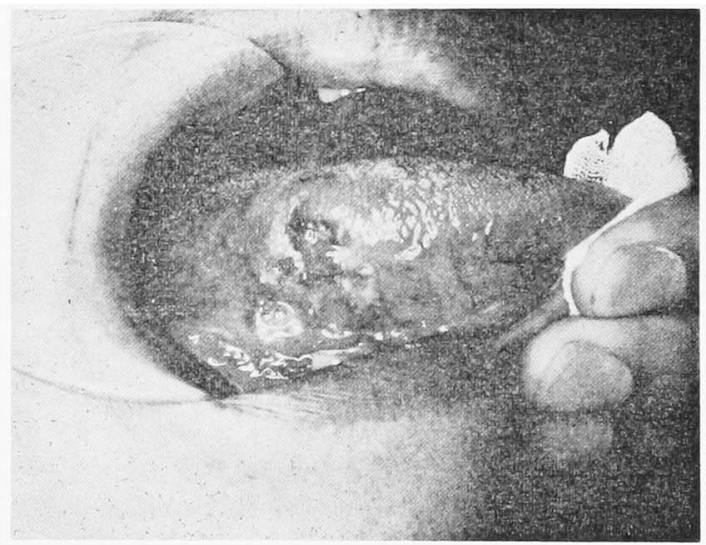

図 2 入院前病態 (50 年 4 月曰日), BLM $30 \mathrm{mg}$, $\mathrm{CQ} 6 \mathrm{mg}$ 投与後

溃痬： $25 \times 15 \mathrm{~mm}$, 硬結 : $30 \times 20 \mathrm{~mm}$ 
表 2 症例 4. N.S. 臨休経過と処置大要
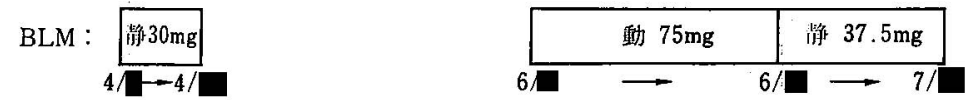

$\mathrm{CQ}$ :
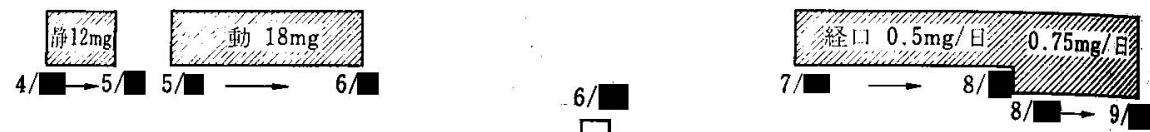

\begin{tabular}{|c|c|c|c|c|c|c|c|c|c|c|c|c|c|c|c|}
\hline \multicolumn{6}{|c|}{ 5/ 入院ך } & \multicolumn{5}{|c|}{ 6/手術一 } & \multicolumn{3}{|c|}{ 8/口姐院— } & & \\
\hline 項目 & $4 / \square$ & $4 / \square$ & $5 / \square$ & $5 / 0$ & $5 / \square$ & $6 / \square$ & $6 / \square$ & $6 / \square$ & $7 / \square$ & $7 \pi$ & 7/ם & $7 / \square$ & $8 /$ & $9 / \square$ & 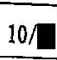 \\
\hline $\mathrm{RBC} \times 10^{4}$ & 443 & 422 & 319 & $3 \dot{0} 0$ & 316 & 353 & 353 & 350 & 277 & 353 & 370 & 362 & 469 & 340 & 379 \\
\hline $\mathrm{WBC} \times 10^{3}$ & 5.5 & 3.6 & 2.7 & 2.8 & 2.3 & 2.8 & 3.5 & 2.6 & 4.8 & 5.5 & 4.5 & 5.2 & 5.3 & 2.4 & 3.1 \\
\hline Thr. $\times 10^{4}$ & 25.3 & 27.9 & 16.3 & 21.4 & 1.9 & 9.9 & 21.9 & 14.0 & 16.6 & 24.4 & 24.4 & 18.5 & 25.3 & 15.3 & 12.9 \\
\hline $\mathrm{Hb} \mathrm{g} / \mathrm{d} l$ & 13.7 & 12.6 & 9.5 & 10.6 & 9.6 & 11.2 & 11.3 & 11.3 & 8.8 & 11.0 & 11.7 & 11.2 & 13.7 & 10.7 & 11.9 \\
\hline T.P. $\mathrm{g} / \mathrm{d} l$ & 7.8 & 6.3 & 6.8 & 7.3 & 6.9 & 7.3 & 7.4 & 7.1 & 6.1 & 6.7 & 6.9 & 6.6 & 8.0 & 7.2 & 7.2 \\
\hline GOT unit & 15 & 20 & 15 & 25 & 29 & 18 & 18 & 16 & 17 & 121 & 25 & 19 & 27 & 19 & 20. \\
\hline GPT unit & 14 & 18 & 19 & 22 & 31 & 27 & 15 & 14 & 22 & 143 & 42 & 21 & 22 & 18 & 19 \\
\hline $\mathrm{Al}-\mathrm{P}$ unit & 9.0 & 6.6 & 7.4 & 7.1 & 7.1 & 7.3 & 6.6 & 6.0 & 4.0 & 6.3 & 7.4 & 5.9 & 6.1 & 5.3 & 5.6 \\
\hline LDH unit & 200 & 140 & 160 & 140 & 200 & 160 & 160 & 180 & 180 & 290 & 150 & 170 & 190. & 200 & 180 \\
\hline
\end{tabular}

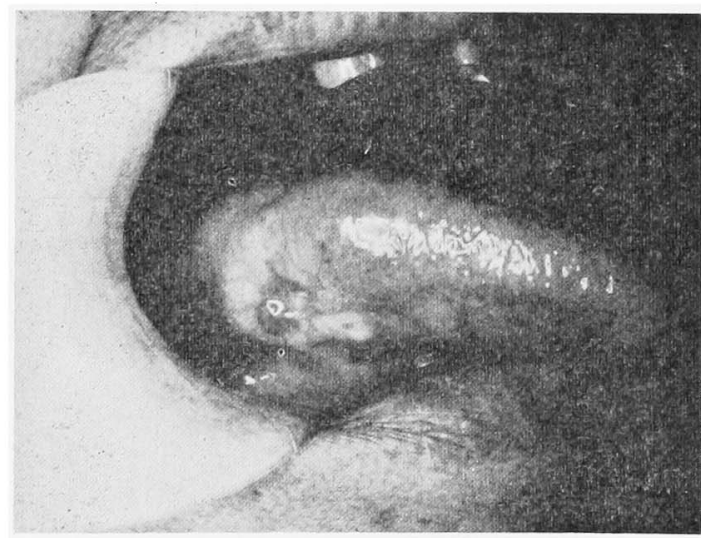

图 $3 \mathrm{CQ} 22 \mathrm{mg}$ (静注 $12 \mathrm{mg}$ ，動注 $10 \mathrm{mg}$ ) 投与 後病態（50年 5 月日日）

溞癔 : $11 \times 11 \mathrm{~mm}$, 硬結 : $13 \times 17 \mathrm{~mm}$

みられた白血球減少は顕著となり，2,500 となったので 一時, 動注を休止した，な拉，この時点での病理組織学 的検査では治療効果は不十分であった．5日間休薬し，

5 月四上り $\mathrm{CQ}$ 動注量を $0.5 \mathrm{mg} /$ 日に減量して再開 した．畽湯はさらに縮小傾向を示し，6月日日には潰瘍 直径は $1 \mathrm{~mm}$ となった。なお，5月ロ日ごろより動注 側での頭髮脱毛が顕著となってきた。白血球の娍少程度

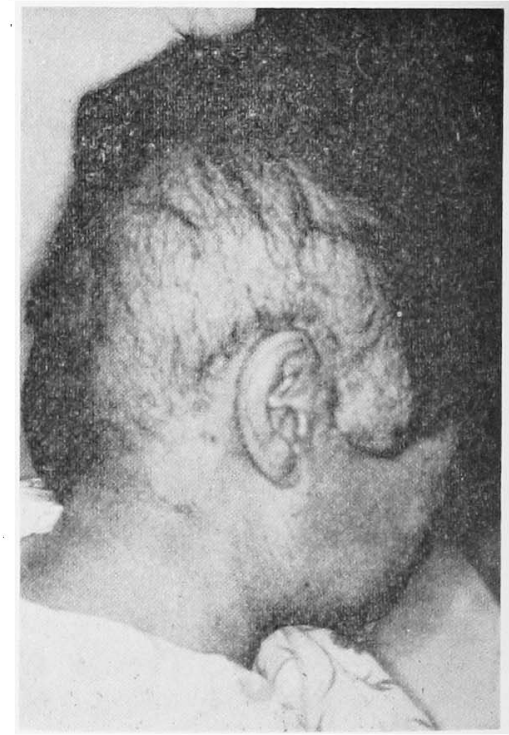

図 $4 \mathrm{CQ}$ 投与量 $30 \mathrm{mg}$ (50年 6 月回） 動注侧頭㙆脱毛影著

おょび傾向は，1 日動注量 $1 \mathrm{mg} /$ 日と $0.5 \mathrm{mg} /$ 日て大差 はみられなかった，6月目に CQ 投与量は $30 \mathrm{mg}$

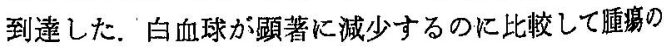




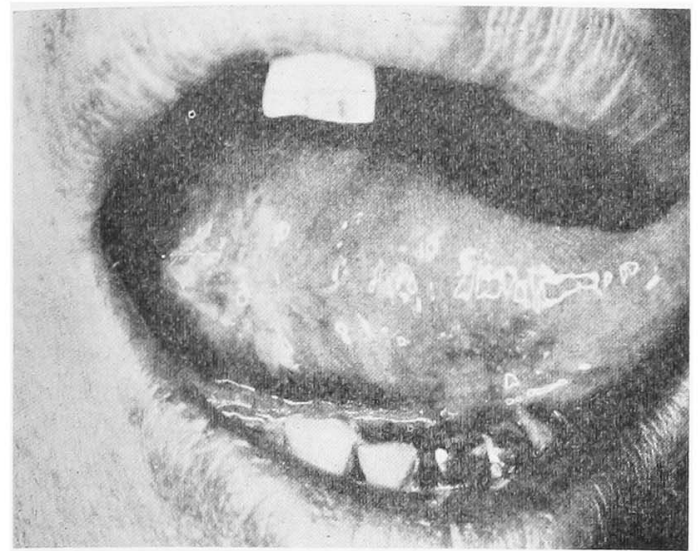

図 $5 \mathrm{CQ}$ 投与量 $30 \mathrm{mg}$ 投与後病態 (50年6月 日)

潰瘍： $3 \times 4 \mathrm{~mm}$ ，硬結：触知せず

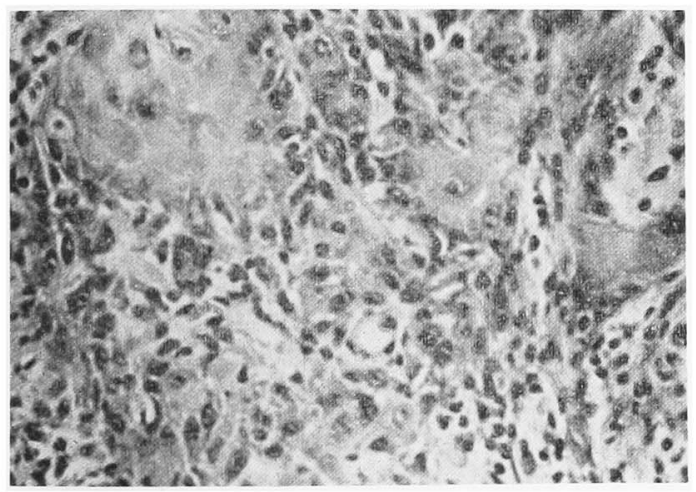

图 6 初診時病理組織所見 $(\mathrm{H}-\mathrm{E}$ 染色， $\times 200)$

縮小傾向は従来の抗腫瘍剂より少ないと判定し，CQ投 与は一応終了し, 白血球数の改善をまって手術療法を適 応することに治療方針を変更した。

手術までの 待機期間中は BLM 3〜 $5 \mathrm{mg} /$ 日の 動注に 変更したが著効は得られず，6月曰日，腫泡に接した部 分に出現した直径 $1 \mathrm{~mm}$ の隆起は次第に增大傾向を示 し，6月目には直径が $4 \mathrm{~mm}$ に增大した，6月曰日 に白血球は 3,500 に改善したので，6月曰日，舌半側切 除と頸部全廓清術を施行し, 舌 row surface には遊離全 層植皮を行った，術後は BLM $7.5 \mathrm{mg} /$ 回，週 2 回投与 $(37.5 \mathrm{mg})$ 乙, 以後は CQ の内服飞変更 $(0.5 \sim 0.75$ $\mathrm{mg} /$ 日) した. 34 日間連続投与した時点で白血球は 2,400に減少したので，本剤の投与を終了した．現在 CQ療法開始より 2 年 3 か月を経過しているが, 局所再 発, 全身転移もない.

病理学的所見：図6は初診時の病理組織であるが，良 く分化した屚平上皮性の腫瘍細胞は胞紧を形成し，深部 へ浸潤する傾向を示している。扁平上皮癌と診断，図 7

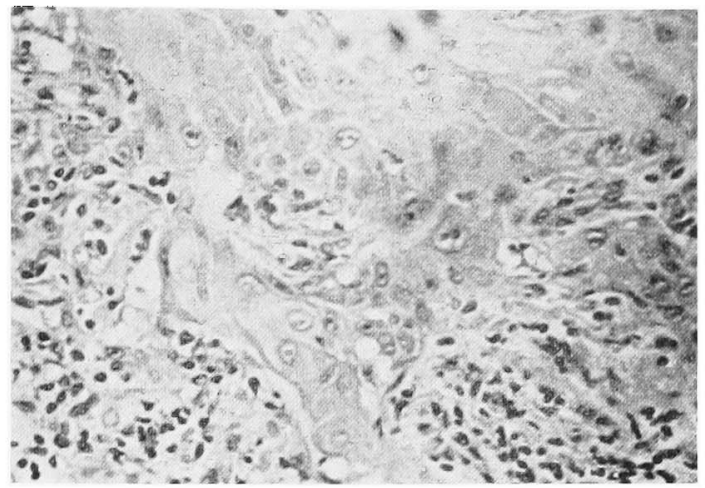

図 $7 \mathrm{CQ} 21 \mathrm{mg}$ 投与後病理組織所見 (H-E 染色, $\times 200)$

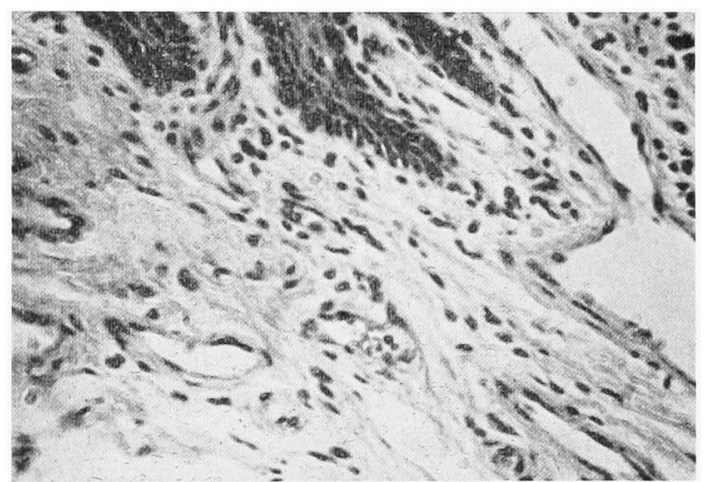

図 8 手衙摘出標本所見 $(\mathrm{H}-\mathrm{E}$ 染色, $\times 200)$ 連激細胞は完全に消失している

はCQを $21 \mathrm{mg}$ (粦注 $12 \mathrm{mg}$, 動注 $9 \mathrm{mg}$ ) 投与時点での 病理組織である。腫瘍細胞は胞单を形成し，結合織内に 浸潤增生している. 尰湯細胞には不十分ながら軽度の変 性傾向を認める。

図 8 は手術により摘出した舌の連続切片の 1 枚である が，舌はほぼ正常の重層扁平上皮により被覆され，瘇湯 細胞は完全に消失していた。

副作用

$\mathrm{CQ}$ の副作用として自血球減少など末梢血液の変化が その特徴の1つとして指摘されている. 白血球減少は偝 注あるいは動注を行った症例で顕著で, 特に動注例で著 明であった，これに対し内服例では減少しないか減少し てるその傾向は軽度ですった。 その減少程度で最低 值 が3,000 以下に減少した症例は3例（33\%）にすきな かったが，投与前と比较して50\%に近い減少を示した 症例を含めると 5 例 (56\%) であった，動注例での投 与量は $1 \mathrm{mg} /$ 日を原則としたが，1例（症例 4) に 0.5 $\mathrm{mg} /$ 日と減量したるのがある。白血球減少程度は両者間 
表 $3 \mathrm{CQ}$ 投与後白血球数の変動

\begin{tabular}{|c|c|c|c|c|c|c|c|c|}
\hline 症 例 & 投与前 & 最低値 & $\begin{array}{l}\mathrm{CQ} \text { 投与 } \\
\text { 経 }\end{array}$ & $\begin{array}{l}\text { 最低値に } \\
\text { 至るむで } \\
\text { の投与期 } \\
\text { 間 }\end{array}$ & $\begin{array}{l}\text { 最低值を } \\
\text { 示したと } \\
\text { きのCQ } \\
\text { 投与総量 }\end{array}$ & $\begin{array}{l}\text { 回復ま } \\
\text { での期 } \\
\text { 間 }\end{array}$ & $\begin{array}{l}\text { 最終 CQ } \\
\text { 総投与量 }\end{array}$ & 㣁 \\
\hline 1. & 6,100 & 3,600 & 静, 動注 & 6 週 & $28 \mathrm{mg}$ & 7 週 & $61 \mathrm{mg}$ & 減少傾向は軽度 \\
\hline 2. & 5,200 & 2,300 & 静, 動注 & 4 週 & $15 \mathrm{mg}$ & 9 か月 & $41 \mathrm{mg}$ & 1 週目より減少傾向 \\
\hline 3. & 5,400 & 2,300 & 静 注 & 4 週 & $20 \mathrm{mg}$ & 13 週 & $49.2 \mathrm{mg}$ & 1 週目より減少傾向 \\
\hline 4. & 5,500 & 2,300 & 静, 動注 & 6 週 & $27 \mathrm{mg}$ & 1 週 & $30 \mathrm{mg}$ & 1 週目より減少傾向 \\
\hline 5. & 5,100 & 3,800 & 静, 動注 & 8 週 & $12 \mathrm{mg}$ & 10 週 & $12 \mathrm{mg}$ & 減少傾向は軽度 \\
\hline 6. & 6,100 & 3,200 & 経 口 & 6 週 & $31.75 \mathrm{mg}$ & 10 週 & $39 \mathrm{mg}$ & 1 週目より減少傾向 \\
\hline 7. & 5,100 & 4,200 & 経 口 & 3 週 & $6.25 \mathrm{mg}$ & 3 週 & $66.75 \mathrm{mg}$ & 隇少傾向は軽度, 死亡 \\
\hline 8. & 7,400 & 8,600 & 経口 & 減少せず & & & $24.75 \mathrm{mg}$ & 死亡 \\
\hline 9. & 6,700 & 6,000 & 経 口 & 減少せず & & & $76.5 \mathrm{mg}$ & 死亡 \\
\hline
\end{tabular}

表 $4 \mathrm{CQ}$ 投与後赤血球数の変動

\begin{tabular}{|c|c|c|c|c|c|c|c|c|c|}
\hline 症 例 & $\begin{array}{c}\text { 投与前 } \\
\times 10^{4}\end{array}$ & $\begin{array}{l}\text { 最低値 } \\
\quad \times 10^{4}\end{array}$ & $\begin{array}{l}\mathrm{CQ} \text { 投与 } \\
\text { 経 路 }\end{array}$ & $\begin{array}{l}\text { 最低値に } \\
\text { 至るまで } \\
\text { の投与期 } \\
\text { 間 }\end{array}$ & $\begin{array}{l}\text { 最低値を } \\
\text { 示したと } \\
\text { きのCQ } \\
\text { 投与総量 }\end{array}$ & $\begin{array}{l}\text { 回復まで } \\
\text { の期間 }\end{array}$ & $\begin{array}{l}\text { 最終 CQ } \\
\text { 総投与量 }\end{array}$ & 诺 & 考 \\
\hline 1. & 453 & 365 & 静, 動注 & 7 週 & $39 \mathrm{mg}$ & 9 週 & $61 \mathrm{mg}$ & & \\
\hline 2. & 381 & 312 & 静, 動注 & 5 週 & $15 \mathrm{mg}$ & & $41 \mathrm{mg}$ & & \\
\hline 3. & 464 & 320 & 静 注 & 8 週 & $43 \mathrm{mg}$ & 17 週 & $49.2 \mathrm{mg}$ & & \\
\hline 4. & 443 & 316 & 静, 動注 & 6 週 & $27 \mathrm{mg}$ & 1 週 & $30 \mathrm{mg}$ & & \\
\hline 5. & 461 & 減少せず & 静, 動注 & & & & $12 \mathrm{mg}$ & & \\
\hline 6. & 355 & 減少せず & 経 口 & & & & $39 \mathrm{mg}$ & & \\
\hline 7. & 433 & 292 & 释 口 & 10 週 & $54.75 \mathrm{mg}$ & 回復せず & $66.75 \mathrm{mg}$ & 死 & 亡 \\
\hline 8. & 452 & 減少せず & 経 口 & & & & $24.75 \mathrm{mg}$ & 死 & 亡 \\
\hline 9. & 427 & 減少せず & 経 口 & & & & $76.5 \mathrm{mg}$ & 死 & 乞 \\
\hline
\end{tabular}

表 $5 \mathrm{CQ}$ 投与後 $\mathrm{Hb}$ 量の変動

\begin{tabular}{|c|c|c|c|c|c|c|c|c|c|}
\hline 症 例 & $\begin{array}{l}\text { 投与-前 } \\
\mathrm{g} / \mathrm{d} l\end{array}$ & $\begin{array}{c}\text { 最低值 } \\
\mathrm{g} / \mathrm{d} l\end{array}$ & $\begin{array}{l}\mathrm{CQ} \text { 投与 } \\
\text { 経路 }\end{array}$ & $\begin{array}{l}\text { 最低値に } \\
\text { 至るまで } \\
\text { の投与期 } \\
\text { 間 }\end{array}$ & $\begin{array}{l}\text { 最低值を } \\
\text { 示したと } \\
\text { きの投与 } \\
\text { 総量 }\end{array}$ & $\begin{array}{l}\text { 回復迄 } \\
\text { の期間 }\end{array}$ & $\begin{array}{l}\text { 最終 CQ } \\
\text { 総投与量 }\end{array}$ & & 请 \\
\hline 1. & 14.5 & 12.1 & 静, 動注 & 6 週 & $28 \mathrm{mg}$ & 10 週 & $61 \mathrm{mg}$ & \multirow{4}{*}{\multicolumn{2}{|c|}{$\begin{array}{l}1 \text { 週目より減少傾向 } \\
\text { 輸血により回復 }\end{array}$}} \\
\hline 2. & 10.8 & 0.87 & 静, 動注 & 3 週 & $15 \mathrm{mg}$ & 回復せず & $41 \mathrm{mg}$ & & \\
\hline 3. & 14.4 & 10.5 & 静 注 & 8 週 & $43 \mathrm{mg}$ & 17 週 & $49.2 \mathrm{mg}$ & & \\
\hline 4. & 13.7 & 9.5 & 静, 動注 & 3 週 & $12 \mathrm{mg}$ & 回復せず & $30 \mathrm{mg}$ & & \\
\hline 5. & 15.3 & 14.4 & 静, 動注 & 5 週 & $8 \mathrm{mg}$ & & $12 \mathrm{mg}$ & & \\
\hline 6. & 11.4 & 10.9 & 経 口 & 4 週 & $21 \mathrm{mg}$ & & $39 \mathrm{mg}$ & & \\
\hline 6. & 13.8 & 11. 2 & 経 口 & 5 週 & $28.5 \mathrm{mg}$ & & $66.75 \mathrm{mg}$ & 㱜 & 亡 \\
\hline 7. & 14.3 & 11.4 & 経 口 & 減少せず & & & $24.75 \mathrm{mg}$ & 死 & 亡 \\
\hline 8. & 13.8 & 13. 2 & 経 口 & 減少せず & & & $76.5 \mathrm{mg}$ & & 亡 \\
\hline
\end{tabular}


表 $6 \mathrm{CQ}$ 投与後血小板数の桨動

\begin{tabular}{|c|c|c|c|c|c|c|c|c|}
\hline 症 例 & $\begin{array}{c}\text { 投与前 } \\
\times 10^{4}\end{array}$ & $\begin{array}{c}\text { 最低值 } \\
\times 10^{4}\end{array}$ & $\begin{array}{l}\mathrm{CQ} \text { 投与 } \\
\text { 経路 }\end{array}$ & $\begin{array}{l}\text { 最低値に } \\
\text { 至るむで } \\
\text { の投与期 } \\
\text { 間 }\end{array}$ & $\begin{array}{l}\text { 最低値炎 } \\
\text { 示したと } \\
\text { きのCQ } \\
\text { 投与総量 }\end{array}$ & $\begin{array}{l}\text { 回復まで } \\
\text { の期間 }\end{array}$ & $\begin{array}{l}\text { 最終 CQ } \\
\text { 総投与量 }\end{array}$ & 供 \\
\hline 1. & 19. 0 & 10.3 & 静, 動注 & 9 週 & $50 \mathrm{mg}$ & 11 週 & $61 \mathrm{mg}$ & 減少傾向は埾度 \\
\hline 2. & 15. 2 & 10.7 & 䋫, 動注 & 3 週 & $10 \mathrm{mg}$ & 回復せず & $41 \mathrm{mg}$ & 減少傾向は軽度 \\
\hline 3. & 19. 0 & 11.1 & 静 注 & 3 週 & $15 \mathrm{mg}$ & 10 週 & $49.2 \mathrm{mg}$ & 3 週目より減少傾向 \\
\hline 4. & 25.3 & 1.9 & 静, 動注 & 6 週 & $27 \mathrm{mg}$ & 8 週 & $30 \mathrm{mg}$ & 3 週目上り減少傾向 \\
\hline 5. & 15.7 & 13. 4 & 哨, 動渓 & 6 週 & $12 \mathrm{mg}$ & 8 週 & $12 \mathrm{mg}$ & 減少傾向は軽度 \\
\hline 6. & 30.9 & 15.7 & 経 口 & 4 週 & $21 \mathrm{mg}$ & 6 週 & $39 \mathrm{mg}$ & 減少傾向は轾度 \\
\hline 7. & 22.1 & 5.3 & 経 口 & 5 週 & $28.5 \mathrm{mg}$ & 回復せず & $66.75 \mathrm{mg}$ & 死亡 \\
\hline 8. & 14.3 & 11.4 & 経口 & 隇少せず & & & $24.75^{\circ} \mathrm{mg}$ & 死亡 \\
\hline 9. & 13.8 & 17.8 & 経 口 & 減少せず & & & $76.5 \mathrm{mg}$ & 死亡 \\
\hline
\end{tabular}

に特に差があるとの印象は持たなかった．白血球の減少 傾向は早いもので 1 週間目より出現していたが，このよ らに早期にその傾向を示したものでは減少程度も大であ った。数的に最低值を示したのは投与開始後 $4 \sim 5$ 週目 で，そのときの CQ 投与量は 12～ $28 \mathrm{mg}$, 平均 $20 \mathrm{mg}$ であった。これら白血球減少に対し特別な処藏は行わな かった（症例 4 には輸血を行った）. 自然に回復する傾 向をみると, CQ 療法終了後早いもので7週，長いもの で9か月を要した 1 例があった。 これに対し内服例での 減少傾向は軽度であったが，1例（症例 6) 約50\%近く まで减少したものがあった，赤血球，血色素の減少は白 血球ほど顕著でなく，むしろ減少傾向はないとの印象を もった，軽度ながら減少傾向を示した例では，投与開始 1 週間目よりその傾向を認めた。

血小板の減少傾向も比較的少なく，7万以下に減少し たものは 2 例 $(22 \%)$ にしかすぎなかった。 これら減少 傾向を示した症例では 3 週目ごろよりその傾向を認め た。症例 4 では投与開始後 6 週で $(27 \mathrm{mg}) 19,000$ に減 少した，本例では白血球の減少も影著であったので，輸 血による改善が必要であった。 しかし全例血小板減少に よると考えられる出血傾向の発現はみられなかった。

同時に経時的に総タンパク量, albumin 量, s-GOT, s-GPT, Al-P, LDH, BUN など検査したが，いずれも 生理的変動内に留まっていた。

このほかの副作用として全身皮店丘疹性発疹をみたも の 2 例，動注侧頭髵の脱毛が 2 例にみられた。脱毛は特 別な処置を行わず，投与終了後数か月をまたすに自然に 発毛回復した.

\section{総括ならびに考案}

Esquinone は荒川, 中尾ら ので, 2-5-bis (1-aziridinyl)-3-(2-carbamoxyloxy-1methoxyethyl)-6-methyl-1, 4-benzoquinone の化学名
表 7 副 作 用

\begin{tabular}{|c|c|}
\hline 発 & 2 例 \\
\hline 脱 & $2 \prime \prime$ \\
\hline 貧 & $1 /$ \\
\hline 白血球減 少 & $5 \prime \prime$ \\
\hline 血小板 減 少 & $2 " \prime$ \\
\hline 血色䋕滅少 & $2 "$ \\
\hline
\end{tabular}

で，構造的には一部は mitomycin C に，一部は Trenimon に類似したアルキル化剂である。本剤の核酸合 成阻害作用機序について中村ら ${ }^{3)}$ は細胞内で還元によっ て活性化された CQ が DNA と結合し, DNA を切 断，低分子化するためと推論している。また金丸ら゙)は RNA，タンバクの合成もCQによって阻害されたと報 告している.

淔谷ら ${ }^{5)}$, 加藤ら ${ }^{6)}$ は L-1, 210 白血病細胞を使用し ての奏験ですぐれた化学療法係数を有し，また臨床応用 に際し，CQとCA の併用が好ましいことを示唆してい る. 臨床的には造血葴器腫㿇7 11, 13), 恶性リンパ腫 ${ }^{12,13)}$, 胃癌, 乳癌, 肺癌など各種莜器固型癌 ${ }^{10,11,13 ~ 29)}$ にそれぞ れ有効であったと報告されている。これら報告での臨床 成績は20～60\%と臓器により一定しないのは当然といえ るが，それぞれほとんどが多剂併用や，他療法との併用 である。特に渡辺ら ${ }^{28)}$, 河原ら ${ }^{24)}$, 浅沼ら ${ }^{27)}$ は肺癌 にCQの BAI (branchial arterial infusion) と放射線 との併用によって著効が得られ，さらに渡辺ら ${ }^{28)}$ は両者 の効果は相乗されたと述べている.しかし一方で, その治 験結果より CQの適応篹囲が広いことは, 逆に CQが 特定悪性腫痬に対し，ほかの制癌剂より際立ってすぐれ た臨床効果を示すといら特長を有しないことを意味する との報告もある ${ }^{13)}$. 一方, 頭頸部癌に対する本阂の治験 報告は少なく，武井ら $\left.{ }^{30}\right)$ の上䫇癌に使用した成績のみで ある.すなわち $\mathrm{CQ}$ 動注とビタミン $\mathrm{A},{ }^{60} \mathrm{CO}$ 照射を 
併用して病理組織学的に追求した結果では，5FU に劣 らない治療効果が得られている。われわれは各種口腔癌 に投与し，その制癌効果について監床的に検討した. 症例 中, 特に $\mathrm{CQ}$ の効果を適格に評価しらる5例の 1 次症 例について考察してみると，他報告にみられるようなす ぐれた効果は得られなかった。 すなわち臨床的には効果 を認めた 4 例も，CQ療法終了後の病理組織検査では細 胞変性傾向は 2 例にしか認められず，またこの変化を認 めた 2 例にもその前後および併用で他剂, 他療法が併用 されていた。 したがって 1 次効果としての成績は好まし くなく, CQ療法終了後, 全例に手術療法を行わねばな らなかった．このことより，先記したごとく既報告例で は併用療法が行われた症例での成績が良好な事実より考 察すると，CQ単独よりも適当な他制癌剤や他療法と併 用することが必要と考兄られる。

対象症例の効果を病理組織学的面より検討してみる と, 肺癌で有効例は扁平上皮癌に集中し, 腺癌は無効で あった ${ }^{28,29)}$ という報告がある反面, 扁平上皮癌である食 道癌では全例無効との報告13)もある. われわれの1次対 象症例は腺様雚胞癌 1 例, 扁平上皮癌 4 例であったが, 臨床的に有効之判定された症例はいずれも扁平上皮癌で あった，われわれの対象症例は例数も少ないため断定す ることはできず，高橋ら ${ }^{18)}$ の述べるごとく CQの抗癌 作用を特定の臓器や組織型に限定することは早計とする 意見が妥当と考えられる. 適応癌の決定や他制癌剤との 併用なと投与法などについては，さらに症例を増やし検 討すべき今後の課題と考光ている.

CQの内服療法について石川 ${ }^{25)}$, 秋谷ら 29 (は内服は 副作用の発現が低いので使用しやすく，特に反覆投与が 可能な点に長所を認めている。しかし斉藤ら ${ }^{11,13)} は$, 経 口投与の効果が CQ 再投与に值するほど著明なるのが 少なく，またほとんどの末期癌患者を再投与可能な状態 にまで改善できなかったと指摘し，これは本剂の経口投 与での“きれ”が劣ることを示唆している，われわれは adjuvant chemotherapy の 3 例を含め, 2 次症例 4 例の 7 例に内服投与を行った。特に䅡極治療として他療法之 併用した 2 次症例では，選択症例が適格でなかったため もあるが，3例は死亡し，1例は投与中に所属りンパ節 に転移を生じた。

副作用としては全身性丘疹性発疹, 動注例で動注侧頭 髮の脱毛がそれぞれ 2 例みられた，本剂の特徽的副作用 とされている造血臓器に対する作用, 特に白血球減少に ついてみると, 動注, 静注例のほらが経口例よりも頻度 が高く，乙かも程度も高度であった，減少傾向を示すも のは投与開始後 1 週目でその傾向がみられ，またこのよ らな症例ではその減少程度も高度であった，減少傾向は 1 回投与量には関係しない印象をるった。すなわち1例 ではあるが，1 $\mathrm{mg} /$ 日動注量で白血球減少がみられたの で $0.5 \mathrm{mg} /$ 日に動注量を半娍したが，やはり減少傾向が
認められ，その減少程度も特に差はなかった。 しかる本 例では術後に adjuvant chemotherapy の意味で本剤の 内服投与を行ったところ, 再度白血球の減少傾向がるら れるよらになった，したがって注射と経口投与による薬 凮の吸収態度よりも, 生体の薬剤に対する感受性の差に よるものと推测される. 赤血球, 血小板などの減少怕 血球減少に比し顕著でなかった，以上のごとく白血球の 顕著な減少は本剤単独療法の限界を示するので, 本剤の 制癌効果を発揮させるためには他療法との併用が必要と 考え，今後この点についての検討を予定している.

\section{結語}

口腔癌 9 例 ( 1 次症例 5 例， 2 次症例 4 例) にCQ療 法を行い, 主として単独による制癌効果について區床的 に検討した。

1. 1 次拝例に対し臨床的に $44 \%$ に効果を認めたが, 病理組織学的検討では効果はみられなかった。

2. 2 次症例に詨する効果は顕著でなかった.

3. 造血缄器に対する副作用, 特に白血球減少が顕著 であった。これ以外の副作用として全身性丘疹性発洿, 動注側での頭髮脱毛がみられた。

4. CQ 単独による治療には限界があり，他制癌剂や 他療法との併用療法が必要と考える.

\section{文献}

1) Arakawa, M., Aoki, T. and Nakao, H.: Effects of carbazil quinone on lymphoid leukemia L-1 210. Gann 61: 4851970.

2) Arakawa, M., Nakao, H. and Aoki, T.: Effects of carbazil quinone transplantable and primary tumors in mice. Gann 61: 5351970.

3) 中村微, 他: 白血病細胞に护ける Carbazilquinone の作用機序. 日血会誌 37: 11974.

4) Kanamaru, R., Asamura, M., et al.: Comparative studies of effects of carbazilquinone (CQ) and Mitomycin C (MMC) on DNA, RNA and protein synthesis of Yoshida Sarcoma (YS) and its substrains. 第 33 回日瘦総会記事 1061974.

5) 植谷忠昭，山田一正 : Carboquone (CQ) の抗 腫陽性に関する実験的研究，一特に in vitro 及び in vivo に打ける他剤との併用奻果の检 討一. エスキノン文献集, No. 1,63 , 三共, 1975.

6) 加藤武俊, 他：吉田肉尰，L 1210 白血病に対 する Carboquone の抗腫富効果および各種制盘

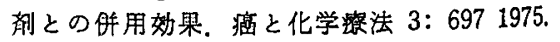

7) 山田一正, 他 : 造血器腫癔に対する Carboquone (CQ) の抗尰瘍性に関する臨床的研究. 工 スキノン文献集，No. 1，107，三共，1975. 
8）長谷川義尚，他：カルバジルキノンによる造血 器尰癔性疾患の治療。瘦の臨床 19：700 1973.

9）長浜交雄，他：Carbazilquinone の抗癌刘果に 関する臨床的研究. 臨床と侀究 50:14631973.

10) 牧野卓磨, 他: Carbazilquinone の抗腫境効果 威する臨床的檢討。臨床と研究 50:3309 1973.

11）斎藤達雄, 他：新抗癌剤 Carbazilquinone の臨 床使用経臨。癌の臨休 17：806 1971.

12）白川茂, 他：Carboquone による恵性リンパ 腫の治療. 癌と化学療法 3: 5331976.

13）斎藤達雄, 松䅄避: 制癌剤の適応と効果, 力 ルハジキノン。痋の臨床 21：1037 1975.

14) 栗田宗次, 他：Carbazilquinone に上る悪性腫 㾤の化学療法. 癌の臨床 17:744 1971.

15) 中野陽興, 他：進行消化器癌に対する Adriamycin, Carbazilquinone, 5FU の併用動注療法 に関する検討。癌と化学療法 1：203 1974.

16）武正勇造：多剤併用に上る化学療法の効果と適 応. 日本臨床 33：107 1975.

17) 服部行麗, 他: 新制癌剂 CARBOQUONE ( スキノン) の臨床使用経臨。癌と化学療法 2: 8391975.

18）高橋秀夫, 他：共同研究によるエスキ人ンの臨 床治験。癌と化学療法 3：80 1976.

19）田村欣一，他：末期痹に対する Carboquoneの 臨床使用経臨。癌と化学療法 3：1259 1976.

20) 松本俊雄, 他：消化器癌に対する Carboquone 単独ならびに 5-Fluorouracil, Mitomycin C と
の併用療法。癌と化学療法 3：257 1976.

21）内嘈純一，他：固型腫源に対する QFC 療法の 経臨。癌と化学療法 3：953 1976.

22）里見隆，他：Carboquone の使用経䮖， 動注療法を中心として——癌と化学療法 4： 7041976.

23) 宮本修, 他：Carbazilquinone による肺癌, 癌性胸膜炎の制癌治療。日癌治誌 9: 1841974.

24）河原正明，他：肺㾇见対する放射線，化学療法 併用治療に気管支動脈内抗癌削注入療法併用の 意義について。肺癌 14：186 1974.

25）石川裕，他：肺瘦患者に対する Carboquone (CQ) の使用経験。診断と治療 64：174 1976.

26) 石原歳久, 他：新抗癌剛 Carboquone (Esquinon）の臨床経験に基づいて。診断と治療 64: 17671976.

27) 浅沼孝和，他: Carboquone (エスキノン®) の 臨床使用経臨，（放射線との併用についての考 察)。現代の臨床 9:170 1975.

28）渡辺洋宇，他：肺癌に対する制癌風 Carboquone の使用释験, 第 2 報: 気管支動脈内注入 (BAI) の効果について。癌と化学療法 1: 85 1976.

29）秋谷消：卵监癌に対する新制癌郕エスキノン の臨床成繢。痹と化学療法 3:265 1976.

30) 武井修, 他：上顎癌に対するカルボコンの効 果に関する臨床病理学的研究. 臨床と研究 52: 1971975. 